\title{
What Intern Nursing Students in Turkey Think About Death and End-of-Life Care? A Qualitative Exploration
}

\author{
Berna Köktürk Dalcali ${ }^{1}$ • Ayşe Sinem Taş ${ }^{1}$ (i)
}

Accepted: 28 June 2021 / Published online: 19 July 2021

(C) The Author(s), under exclusive licence to Springer Science+Business Media, LLC, part of Springer Nature 2021

\begin{abstract}
This descriptive qualitative study was planned to determine the views of intern nursing students about death and end-of-life care. The study was completed with 12 intern students based on the criterion of data saturation. As a result of the study, the categories of 'end,' 'uncertainty,' 'fear,' 'beginning,' 'helplessness' under the theme of death, 'ensuring peace,' 'continuing communication' 'providing psychosocial/ spiritual support,' 'acting in conformity with principles of ethics/morality,' 'continuing to provide physical care,' 'supporting the family,' 'making the best use of the limited remaining time or helping the patient's last wishes come true' under the theme of end-of-life care emerged.
\end{abstract}

Keywords Death $\cdot$ End-of-life care $\cdot$ Dying patient $\cdot$ Intern nurses

\section{Introduction}

The phenomenon of death as the inevitable end of a living being has always occupied a place in the human mind (Özarslan, 2017). As well as being an inevitable and natural phenomenon, death is a societal and cultural phenomenon just as all other biological characteristics of the human being (Bakan \& Arli, 2018; Cerit et al., 2021; Jang et al., 2019; Shaw \& Abbott, 2017; Şahin et al., 2016). Death, which used to be perceived as a natural and integral part of life in the premodern period, is today viewed as an abnormal situation. Additionally, today, death is perceived to be more like a medical diagnosis rather than an absolute fact for the living being and viewed as preventable and deferrable. This change in perception and attitude stems to a large extent from developments

Ayşe Sinem Taş

atas@bandirma.edu.tr

Berna Köktürk Dalcali

bdalcali@bandirma.edu.tr

1 Department of Nursing Fundamentals, Faculty of Health Sciences, Bandırma Onyedi Eylül University, Bandırma, Balıkesir, Turkey 
in medical science. These developments give rise to the medicalization of life and death (Jang et al., 2019; Özarslan, 2017).

Health professionals, particularly nurses, often face death and the dying patient. For nurses to be able to provide end-of-life care, they should have effective communication skills, the ability to cooperate with others and complex competencies such as providing emotional support and compassionate care (Adesina et al., 2014; Carey, 2021; Dalcalı et al., 2020; Jeffers, 2014; Kudubes et al., 2021). To provide holistic end-of-life care, the patient's social, psychological, mental and physiological needs should be met, and attention should be paid to challenges to be faced not only by the patient but also by their family (Jeffers, 2014; Kisorio \& Langley, 2016; Kudubes et al., 2021). It is stated that the newly graduated nurses of today are more likely to offer care to dying patients, and thus, it is important that they launch their professional careers with a view toward providing the patient and their family with good-quality holistic care (Dobrowolska et al., 2019; Gibbins et al., 2011; Shaw \& Abbott, 2017).

It is expected from nursing students to be prepared for providing end-of-life care by their undergraduate education in nursing. However, it is known that education about end-of-life care is not included in the large majority of nursing curricula (Allen, 2018; Conner et al., 2014). As per the review of the relevant literature, student nurses have reported that the education they received about end-of-life care was not sufficient in their undergraduate nursing education, they felt shortcomings in supporting and providing care to the dying patient and their families, and they had negative feelings while providing end-of-life care (Adesina et al., 2014; Anderson et al., 2015; Gillan et al., 2016; Mak et al., 2013). During nursing education, students are given the responsibility of sustaining survival, and in this respect, along with failure to prevent death, nursing students who perceive themselves to have the responsibility to ensure the individual's survival have different emotions and thoughts. In several studies performed with nursing students, it has been put forward that students had anxiety about providing end-oflife care, and their knowledge and skills were inadequate (Gillan et al., 2013; Li et al., 2019). Providing end-of-life care may be frightening for nursing students who have not been sufficiently prepared for end-of-life care. It is likely that nursing students will be unable to offer good-quality end-of-life care due to feelings such as indecision, discomfort, helplessness, anxiety and trouble while providing end-of-life care during their professional careers (Ferguson \& Cosby, 2017). Nursing students' emotions and thoughts about death and their attitudes toward the dying patient have a quite significant effect on the quality of care they will offer to the patient who is approaching death (Henoch et al., 2017). Considering that the knowledge base and skills necessary for providing the dying patient with care are shaped during university years, it is important to analyze nursing students' views about end-of-life care. 


\section{Materials and Methodology}

\section{Research Type and Design}

This is a descriptive study designed to analyze intern nursing students' views about death and end-of-life care. In the study, the qualitative research design of phenomenology was used.

\section{Research Population and Sample}

The population of the study comprised students who continued to have internship education at the Department of Nursing of the Faculty of Health Sciences. It is set forth that there is no limit for the sample size of qualitative studies, and the sample size may be designated in light of the research question and aim. In qualitative research, rather than generalizing the research results, it is important that the phenomenon under consideration is analyzed in depth. Thus, satisfaction of the criterion of 'attaining theoretical saturation' is put in place in the data collection process. Theoretical saturation is accomplished when the data gathered by the researcher are reduplicated, and hence, novel data are not obtained (Erdoğan et al., 2014; Kümbetoğlu, 2017). In this respect, the sample of the study was composed of 12 students (Erdoğan et al., 2014; Kümbetoğlu, 2017).

\section{Data Collection}

The data were collected using a 'Semi-Structured Interview Guideline for Students' which was prepared in light of studies performed about ethics (Dobrowolska et al., 2019; Gillan et al., 2013; Laporte et al., 2020; Li et al., 2019). As the research was conducted during the COVID-19 pandemic period, the data were collected through Zoom (software). The Zoom meetings were held on the basis of the students' perceptions about death, experiences they had about end-of-life care in their clinical practice, roles and responsibilities they perceived about end-of-life care and challenges they thought they would be confronted with during end-of-life care (Dobrowolska et al., 2019; Gillan et al., 2013; Laporte et al., 2020; Li et al., 2019). The online meetings took $20-40 \mathrm{~min}$, with an average duration of $28 \mathrm{~min}$.

\section{Data Analysis}

The content analysis method was used to analyze the data. After all meeting records were listened to and transcribed by the researchers into texts through the computer, firstly, themes, and then categories were identified based on the meeting data. In this study, the analysis phases were as follows: (1) transcribing the data, (2) coding the data, (3) creating categories and themes, (4) organizing the categories and themes, and (5) noting the findings down and commenting about them. After the identified categories and themes were read, and the researchers reached a consensus on these categories and themes, they were submitted to three 
experts for review. In the next step, after expert opinions were received, the latest versions of the categories and themes were created (Graneheim \& Lundman, 2004; Kümbetoğlu, 2017).

\section{Ethical Aspect of the Research}

For conducting the study, ethical approval was obtained from the Health Sciences Non-Invasive Studies Ethics Committee of Bandırma Onyedi Eylül University (Date:13.11.2020 Numbered:2020-47), and permission was received from the Faculty of Health Sciences where the research would be carried out. The research process complied with the principles of the Declaration of Helsinki. Before starting the study, the participating nursing students expressed their verbal consent to be included in the study.

\section{Findings}

Descriptive data about the participant nursing students are exhibited in Table 1.

In this study, where nursing students' views about death and end-of-life care were explored, three themes were identified (Table 2). The findings are presented under the themes of 'Death' and 'Efforts Made/Should Be Made in End-of-Life Care.'

Table 1 Descriptive data of the participants

\begin{tabular}{lllll}
\hline Gender & Age & $\begin{array}{l}\text { Having received education } \\
\text { about end-of-life care }\end{array}$ & $\begin{array}{l}\text { Having had the experience } \\
\text { of providing care to a dying } \\
\text { patient }\end{array}$ \\
\hline 1 & M & 21 & Yes & No \\
2 & F & 20 & Yes & Yes \\
3 & M & 21 & Yes & No \\
4 & F & 22 & Yes & Yes \\
5 & F & 22 & Yes & No \\
6 & F & 21 & Yes & No \\
7 & F & 20 & Yes & No \\
8 & F & 21 & Yes & No \\
9 & F & 20 & Yes & Yes \\
10 & F & 21 & Yes & Yes \\
11 & F & 20 & Yes & No \\
12 & F & 20 & Yes & No \\
\hline
\end{tabular}


Table 2 Views of the participants about death and end-of-life care

\begin{tabular}{ll}
\hline Theme & Category \\
\hline & End \\
Uncertainty & Fear \\
& Beginning \\
& A part of life \\
& Helplessness \\
& Ensuring peace \\
& Alleviating physical pain/ache \\
& Continuing communication \\
Eeath & Providing psychosocial/spiritual support \\
& Acting in conformity with principles of ethics/morality \\
& Continuing to provide physical care \\
& Supporting the family \\
& Making the best use of the limited remaining time or \\
& helping the patient's last wishes come true \\
\hline
\end{tabular}

\section{Death}

\section{End}

The most important point emphasized by the participants about death was that death is an end. While some students accounted for the concept of an end as the end of physiological processes, some students adopted a more emotional approach.

It is an end. That is, it is finished. This is the end of everything in this life.

It is the state in which all functions stop. (S2, F, 20)

\section{Uncertainty}

While the participants defined the concept of death, they often identified it with the concept of uncertainty. It was ascertained that not only was the concept of uncertainty identified by the students with when and how death would take place, but the students also drew attention to thoughts about the uncertainty about the aftermath of death.

Death is actually a very frightening issue when I think of it, time seems like something which will make me go crazy as I think of eternity. Psychologically, I do not know, the fact that we do not know what will happen as of this moment in eternity is such an unsettling situation. (S6, F, 21) 


\section{Fear}

Regarding the concept of death, the participants often mentioned the feeling of fear. It was noteworthy that the students' fears mostly did not pertain to their own death, and a large majority of them were afraid of losing one of their family members. Moreover, the students stated that they viewed death as a transition to eternity, and they were afraid of this eternity.

That is, in my opinion, fear for me. Until now, I have not lost any very old relative. I have not had this feeling yet. However, when I see my friends who experience this feeling, I am excessively affected. I feel bad, I feel fear, in my opinion. (S5, F, 22)

\section{Beginning}

It was found that a large part of the students perceived death as a new beginning. It was discerned that all students who perceived death as a beginning identified it with belief in the afterlife which is a tenet of the religion of Islam.

Since my childhood, for me, death has been an incident that I embraced along with its religious aspects to a larger extent. For instance, when I was little, I used to think everything had an end. However, now, at this age, I consider death as a new beginning. (S10, F, 21)

\section{A Part of Life}

The participants said they viewed death as a part of life. It was ascertained that they thought death is also a fact just as life itself, and the cycle of life would continue only this way.

Professor, in my opinion, if a person's life comes to an end, it is a part of life. Actually, I see death not as the end of life, rather, as part of life. If there is life, there is also death in the end. (S12, F, 20)

\section{Helplessness}

It was identified that a large proportion of the participants identified death with helplessness. The students expressed that they had nothing to do with death and felt helpless when their loved ones felt sorrow due to a death.

The person feels such helplessness, I cannot do anything, their family is helpless. For instance, when I had an internship in the palliative care service, I observed paralyzed patients and patients at the last stage of cancer. I even witnessed these things, as well as a situation where a doctor asked a family to get themselves ready (for death), and as of that moment, this 
speech made me very sad. I have been saddened by people's helplessness. (S6, F, 21)

\section{Efforts Made/Should Be Made in End-of-Life Care}

\section{Ensuring Peace}

The participants stated that their basic responsibility in end-of-life care was to ensure peace for the patient. They said they thought it is important to value patients as they deserve at the end of their lives, and for achieving this, it is essential to ensure the continuation of the patients' daily routines, fulfill their wishes and continue to have effective communication with them.

Ensuring that the patient passes away by feeling valued as they deserve, by having what they need. Even if the patient is going to die, a peaceful death can be attained by doing the things that they do in their daily routine. (S2, F, 20) For instance, the patient that I mentioned liked reading the Holy Qur'an. In the simplest terms, reading the Holy Qur' an may please the patient, and this actually varies from patient to patient. This may be having them listen to music, or approaching them and asking how they are today, even if they do not respond, making them feel that you are next to them is great for that patient. For example, in my internship, whenever I said, "Good morning, how are you today? I will measure your vital signs today," I received responses such as, "My dear daughter, always smile like this please, be like this, this is enough for us." (S4, $\mathrm{F}, 22)$

\section{Alleviating Physical Pain/Ache}

Almost all participants agreed that the patient should not have pain in end-of-life care, and their pain should be alleviated. It was observed that the students who directly saw patients suffering pain in end-of-life care were more sensitive to this topic. The students believed that, on the last days of their lives, patients deserve to have days without pain and agony, where they are able to breathe comfortably.

Ah, having no pain is important. When I think of death, I always think about my last patient, they passed away by vomiting in the end, and really, they had too much pain, it was visible from their face, they were groaning. I think they were supposed to die without experiencing that. (S10, F, 21)

\section{Continuing Communication}

The participants stated that verbal and non-verbal communication with the patient should be continued. It was noteworthy that the students emphasized that patients could hear care providers even if they are unconscious, and thus, it is definitely important to continue to have communication with them. Moreover, some students put forward that continuing to communicate with the patient is of importance also 
to the creation of an environment of mutual trust with the patient and the feeling of being valued by the patient.

By talking to the patient, by listening to the patient's problems if they are conscious, or even if they are unable to talk, simply by holding their hand, by making them feel relaxed, in the end, the last sensory organs that a human being loses are the ears, even if the patient is unconscious, we can support that patient simply by talking to them. (S2, F, 20)

\section{Providing Psychosocial/Spiritual Support}

All participants stressed the importance of providing the patient with psychosocial support in end-of-life care. The students said psychosocial support occupies a crucial place in holistic care, and this is even more crucial especially in end-of-life care.

In end-of-life care, yes, physical needs can be met. Yes, physical needs should be met. However, here, I think support should be given in terms of the spiritual aspect, that is, the emotional aspect rather than physical activities or the physical condition. In other words, for instance, assuming that I were in the patient's shoes, I am already facing something like death, with an end, it is already there, but now I know that it is close to me, my loved ones feel sorrow and are worried for me. This is why I think emotional support should be more at the forefront. (S9, F, 20)

In particular, the students who had the chance to observe end-of-life care during their clinical practice stated that shortcomings in the psychosocial care offered to patients were disturbing for them, and they did not want to have such a bad experience.

Frankly speaking, I do not think that proper psychosocial care was provided either by the patient's relatives or the nurses. Not many patients were conscious, there were some patients who were conscious, but just a small number. Not much attention was paid in the recent periods. Just after dressing the wounds and applying therapy, the nurse was leaving... Frankly speaking, I would not like to have such an experience, I was afraid of having such an experience. Well, we talk about holistic care; actually, it was not in place in the palliative care service. (S2, F, 20)

The participants argued that it is necessary to support the activities the patient wants to perform in the end-of-life period in accordance with their religious beliefs, and an opportunity should be given to the patient in this respect. It was noteworthy that the students underlined that respecting the patient is essentially important, and no recommendation about any practice should be proposed to the patient.

The end of life is a very complicated period. In this period, priority should be attached to the patients' needs. For instance, in our case, when the death of a patient approaches, prayers are said, zam-zam water is given to the patient, I 
think they all should be allowed as it seems that only then it will be a peaceful death. This is because we are raised with this cultural tenet. (S11, F, 20)

\section{Acting in Conformity with Principles of Ethics/Morality}

A large part of the participants said they observed that the patients were neglected by both the nurses and the family members in the end-of-life care process. The students thought it is necessary to behave more meticulously toward patients while providing the patients with end-of-life care, continue the communication with the patients and apply meticulous care by using their nursing roles.

I do not know how to say, over there, the patient is unconscious, the patient does not have awareness about anything. As nurses, we are not supposed to neglect the care process by presuming that the patient will die anyway. As this was what I observed mostly, it lied deep down in me. (S11, F, 20)

Let me tell you, there was a patient in the palliative care service. I was very sad about that patient. The woman was living completely tied to a bed for two and a half months and had deep pressure sores. It was quite challenging; when we visited her every day, she could not speak but heard and understood us. In each visit, we were initially talking and having a chat. As if we talked to a normal ordinary person, we were talking to her in the same manner. Well, she was smiling with her eyes, maybe she was not responding, but she was at least looking in our eyes with hers and so on. Afterward, her spouse said, "Do not try too hard, she will die anyway." Well, it is very bad that she heard that from a loved one. Thus, saying, 'Anyway she will die, cannot hear me, let me do my job alone and go without establishing any communication', or not responding in a calming manner when she had high anxiety while asking me questions, and leaving her just by providing her with the treatment; all these are not okay. (S9, F, 20)

\section{Continuing to Provide Physical Care}

The participants thought that it is important to continue to provide patients with physical care during end-of-life care. The students stated that they faced negative conditions such as self-care deficiencies and pressure sores as patients were not provided with sufficient physical care in the end-of-life care period, and it is necessary to pay attention to this issue.

I thought that the patient could have much better care before they were in this condition. We were dressing the wound of the patient to whom we gave the care, and really, it was the worst case I have ever seen. Well, before the patient was in this condition, much better care could have been offered to them. Even if the patient would die, I was very sorry that they were in that condition. I felt our shortcomings in care... In that last period, we should raise the quality of care. We should change that thought. We should not view them just as a patient who is highly likely to die. (S2, F, 20) 


\section{Supporting the Family}

All participants thought that end-of-life care is not limited solely to the patient, and it is important to support the family, too, in this period. The students set forward that end-of-life care and losing loved ones are not easy for the family, and the emotions and thoughts of the relatives of patients are important.

Of course, patient relatives also get very exhausted psychologically in this period. We also experienced it, my parents were becoming very stressed in a highly troubled period. Actually, after the patient dies, it gets a new dimension. This time, regret starts. I wish I had done that; I wish I had taken better care [of the deceased]. As that person is no longer alive, compensating for regrets becomes impossible. In this period, providing the family with psychological care and support is much more important. (S2, F, 20)

Yes, the patient is going to lose their life after a while, but there are individuals who will continue to live. Actually, I think the diagnosis should be made also about the family's thoughts, feelings and emotions. In general, we skip it because we generally try to take care of the patient over there. That is, what the patient's relative feels [is also important]... (S3, M, 21)

\section{Making the Best Use of the Limited Remaining Time/Helping the patient's Last Wishes Come True}

The vast majority of the participants underlined that it is important that the patient spends their last period by enjoying it with their family and loved ones. Moreover, the students thought that the care provided by nurses during this period is a significant factor determining whether the patient spends their remaining life enjoying it. The students said it was important to fulfill the patient's last wishes in this period if possible.

It is care that requires more attention because you can have compensation in incidents that do not affect the duration of the life of an ordinary human being. However, the patient [in this case] does not have a long time in end-of-life care, the better we can provide them with care, the better their remaining time in this life will be spent, the better they will be spending their remaining time. When you empathize, you understand its value better. ... and it is necessary to be more careful and meticulous while providing care. (S3, M, 21)

At this stage, in my opinion, one of the most significant points is to show respect to the patient. In other words, it should be ensured that the patient spends this last stage in life in the way they would like to spend it. Maybe, the patient will not want to have painful invasive interventions but will desire to be with their family in a peaceful atmosphere. This can be attained. (S9, F, 20) 


\section{Discussion}

The basic philosophy of nursing focuses on the person's individualism and uniqueness and requires that the individual be evaluated as a whole in each situation in which they are placed (Carey, 2021; Izumi et al., 2012). Today, prolongation of the lifespan of people along with the aging of the population and development of technology makes nurses be more frequently confronted with the experience of providing dying patients with care (Adams et al., 2011). Thus, it is important to identify the views of intern nursing students about end-of-life care, as these views are considered to be likely to affect the quality of end-of-life care.

The findings obtained in this study which analyzed the views of intern nursing students about death and end-of-life care are discussed in the context of the themes of 'death' and 'efforts made/should be made in end-of-life care.' In the relevant literature, it was put forward that behaviors exhibited by nurses while providing a dying patient with care could be associated with the nurses' experiences, perceptions and emotions (Wang et al., 2018). In the context of this study, the categories of 'end,' 'uncertainty,' 'fear,' 'beginning,' 'a part of life,' and 'helplessness' were derived from the participants' perceptions about death. In the study by Şahin et al. (2016), it was similarly reported that students defined death with concepts such as a new beginning, the end of life, annihilation and being unable to see loved ones again. The result of this study was in a similar vein to several studies in the relevant literature (Baykara et al., 2020; Temelli \& Cerit, 2019; Uysal et al., 2019; Yiğitoğlu \& Özer, 2012). On the other hand, it was discerned that phenomena such as helplessness and being unable to admit were not addressed often in previous studies. The period when the data of this study were gathered coincided with a period when there was a high number of deaths stemming from the COVID-19 pandemic, and hence, it is considered that the students might have felt helplessness due to being confronted frequently with the news of deaths.

Upon the review of the students' views about death, it was ascertained that a large majority of them thought that death was an end. Considering the definition of death from the biological perspective, death is the end of life functions (Cerit, 2019). Thinking about the education nursing students receive, it is an expected result that these students think about biological death and perceive death as an end. Certain points to which the students in this study most frequently referred were the categories of uncertainty and fear. Along with disruption of physical functions, loss of control and the unknown death process, death may be accompanied by emotional problems such as fear and anxiety in human beings (Yang et al., 2019). Likewise, in the study performed by Temelli and Cerit (2019) with palliative care nurses, it was asserted that death could sometimes be fearful. A large part of the students agreed that death is not only an end to this world but also a new beginning. It is considered that this thought was affected by their belief in the afterlife, a tenet of the religion of Islam common in Turkey where the research was conducted. This is because death is not only a part of life but also a phenomenon that is influenced by beliefs about culture, age and religion 
(Bryan, 2007; Cerit, 2019; Parry, 2011). In Muslim-majority countries like Turkey, death is considered to involve the spirit of the human being getting separated from the body and rising toward the presence of God (Cerit et al., 2021). It is believed that this point of view was effective on the finding that some students in this study perceived death as a new beginning. The students thought that death is a part of life and an incident that is supposed to take place. Death is viewed as an event that takes place in the course of time and perceived as a part of the cycle of life (Baykara et al., 2020). One of the significant points in the statements of the students who defined death as a part of life was that death would be acceptable after human beings have reached their targets. In the study by Temelli and Cerit (2019), it was identified that nurses viewed death as an inevitable part of life.

Regarding the theme about the practices the students fulfilled and thought that should be fulfilled during end-of-life care, the categories of 'ensuring peace,' 'alleviating physical pain/ache,' 'continuing communication,' 'providing psychosocial support,' 'acting in conformity with principles of ethics/morality,' 'providing spiritual support,' 'continuing to provide physical care,' 'supporting the family' and 'making the best use of the limited remaining time/helping the patient's last wishes come true' came to the forefront. The primary goal in the attitude adopted toward the patient as they approach death is ensuring that the remaining time of their life has good quality and that death takes place in a dignified manner. Not the disease, but the patient and their family as a whole are placed at the center of the care. The basic needs of patients and their families such as pain management and mental, moral and social support which are covered by end-of-life care should be satisfied (Alkan et al., 2020). In the study carried out by Dong et al. (2016) with nurses who offered care to cancer patients in their terminal period, it was emphasized that the care process should include spiritual care, symptom management, providing comfort and preparing the family for death. In the meta-analysis carried out by Zheng et al. (2016), it was determined that topics such as pain management, supporting the family and providing the patient with psychosocial support came to the forefront in the context of end-of-life care provided by nurses. Moreover, in qualitative studies about end-oflife care in the literature, similar themes such as continuing to have hope, providing spiritual care, adopting a multidisciplinary approach, cooperating with the patient and their family, providing also the family with psychosocial support and preparing the family for the mourning process have come forward (Brooks et al., 2017; Dalal \& Bruera, 2017; Dong et al., 2016; Liu \& Chiang, 2017). Nurses who provided endof-life care have thought that, to provide good-quality end-of-life care, pain should be alleviated, physical care should be continued properly, effective teamwork should be in place, and the patient and their family should be provided with physical and emotional peace and spiritual comfort (Huang et al., 2016; Kisorio \& Langley, 2016; Wong et al., 2020). It was found that one of the points the students underlined most in end-of-life care was the necessity to put the patient's pain/ache under control. Likewise, in the study performed about end-of-life care by Zheng et al. (2015) with the participation of oncology nurses, it was noted that the most important point was pain control. As per the review of several studies carried out with newly graduated nurses and student nurses about end-of-life care, it was determined that alleviating the patient's pain and ache was one of the most prominent points (Barrere \& 
Durkin, 2014; De Witt Jansen et al., 2017; Glover et al., 2017; Tamaki et al., 2019; Zheng et al., 2016).

The students in this study said the patient should have the required meticulous attention in end-of-life care. The students also advocated the idea that care is not solely limited to the treatment, but nurses and patient relatives should provide the patient with meticulous care. Barrere and Durkin (2014) argued that nurses' sensitivity toward the patient continued in end-of-life care, and nurses tried to provide good-quality care. Considering that one of the most important responsibilities in the profession of nursing is providing care in light of ethical principles, nursing students' sensitivity toward end-of-life care is a phenomenon that is important in terms of the quality of the care they will provide (Cerit et al., 2021; Gómez-Vírseda et al., 2020; Hsu et al., 2021; Leget \& Kohlen, 2020; Özgönül et al., 2020; Svenaeus, 2020).

It was identified that the students participating in this study highlighted the importance of providing the patient with psychosocial and spiritual support. On the other hand, there were also students who thought that what they could do about their own areas of care was limited in terms of providing spiritual support. Likewise, Dobrowolska et al. (2019) reported an increase in nursing and medical students' awareness about psychosocial and spiritual topics in end-of-life care. Zheng et al. (2015) found nurses to agree that they should support patients spiritually in end-oflife care. In addition to the aforementioned findings, it is also stated in the literature that nurses avoided establishing an emotional relationship with the dying patient, and they had difficulty in communicating with the patient (Cerit et al., 2021).

Another category emphasized by the participants about end-of-life care was to continue to provide physical care. It was observed that especially the students who had faced more pressure sores during their clinical practice of palliative care were more sensitive regarding this topic. It is considered that the students' particular sensitivity toward this topic arose from their thoughts that death should take place in a manner that would respect human dignity. Temelli and Cerit (2019) observed that, until the final moments, palliative care nurses fulfilled nursing activities such as changing the patient's position in bed and dressing their pressure sores.

The participants in this study asserted that the family needs as much support as the patient, and occasionally, they need even more support than the patient in endof-life care. Besides providing the patient with physical and spiritual care, it is necessary to give psychosocial support to the family. During their process of providing care for the dying patient, nurses are supposed to consider the needs of not only the patient but also the patient's family (Tüzer et al., 2020; Üzen Cura, 2021). Furthermore, a study which explored family experiences about end-of-life care nursing emphasized that the communication between the nurse and the family is quite important, and issues such as providing dying patients' families with information and support and making joint decisions with them while planning the care process are a part of end-of-life care (Noome et al., 2016). Zheng et al. (2015) claimed that not only is the primary focus of nurses on the patient in end-of-life care, but nurses also realize that it is important to support the patient's family in this process. In this study, the students thought that it was important to make the best use of the patient's remaining limited time and fulfill the patient's last wishes in life. At this point, it was 
identified that most students viewed the patient's family as a support mechanism, and the students thought it is important to present the opportunity for the patient to spend their remaining time with their family. Kisorio and Langley (2016) stated that it is important to show respect to the patient's wishes and preferences in end-of-life care and ensure that adequate interaction is established with the family.

\section{Limitations}

Among the students who were interviewed within the scope of this study, only 4 had the experience of providing a dying patient with care. The remaining 8 patients had not had such an experience. This was an important limitation in this study, because past experiences have a significant place in the shaping of attitudes toward providing care for a dying patient. The results of the study reflect the views of only the interviewed students, and they cannot be generalized.

\section{Conclusion and Recommendations}

The findings of this study indicated that, about the concept of death, the intern nursing students had feelings of the end, uncertainty, fear and being unable to admit a situation, and they thought, in end-of-life care, physical pain/ache should be alleviated, communication should be continued, psychosocial support should be provided, more meticulous care should be given, spiritual support should be provided, physical care should be maintained, the family should be supported, efforts should be made to make the best use of the remaining time of life, and the remaining time should be used as the patient desires. Moreover, they considered that they would be emotionally affected while providing end-of-life care, but they would get used to the death of patients and would not be affected by it in the course of time.

In light of these findings, to provide patients and patient families with effective end-of-life care, intern nursing students should firstly acquire insights about their own behaviors. It is recommended to add courses about end-of-life care to the nursing curriculum, provide students with training simulations about the care to be offered to the dying individual and their family, identify the worries and attitudes of students in this process and encourage students to talk about their emotions and thoughts about death. Additionally, it is recommended to address topics related to end-of-life care in activities such as seminars and conferences to be held at the university. Furthermore, providing consultancy services and exploring the topic concretely through case discussions are recommended.

Acknowledgements The authors thank all the students who participated in the study.

Funding The authors did not receive support from any organization for the submitted work. No funding was received to assist with the preparation of this manuscript. No funding was received for conducting this study. No funds, grants, or other support was received.

Declarations 
Conflict of interest The authors have no relevant financial or non-financial interests to disclose. The authors have no conflicts of interest to declare that are relevant to the content of this article. All authors certify that they have no affiliations with or involvement in any organization or entity with any financial interest or non-financial interest in the subject matter or materials discussed in this manuscript. The authors have no financial or proprietary interests in any material discussed in this article.

Ethical Approval All procedures performed in studies involving human participants were in accordance with the ethical standards of the of the institutional and/or national research committee and with the 1964 Helsinki Declaration and its later amendments or comparable ethical standards. The study was approved by the Health Sciences Non-Invasive Research Studies Ethics Committee of Bandırma Onyedi Eylül University and the permission was received from the Faculty of Health Sciences where the research would be carried out.

Consent to Participate Informed consent was obtained from all individual participants included in the study.

\section{References}

Adams, J. A., Bailey, D. E., Anderson, R. A., \& Docherty, S. L. (2011). Nursing roles and strategies in end-of-life decision making in acute care: A systematic review of the literature. Nursing Research and Practice. https://doi.org/10.1155/2011/527834

Adesina, O., DeBellis, A., \& Zannettino, L. (2014). Third-year Australian nursing students' attitudes, experiences, knowledge, and education concerning end-of-life care. International Journal of Palliative Nursing, 20(8), 395-401. https://doi.org/10.12968/ijpn.2014.20.8.395

Alkan, A., Yekedüz, E., \& Şenler, F. Ç. (2020). Ölmekte Olan Kanser Hastalarında Semptom Kontrolü ve Yaşam Sonu Desteği. Türkiye Klinikleri Tıbbi Onkoloji-Özel Konular, 13(1), 75-82.

Allen, M. L. (2018). Examining nursing students' stress in an end-of-life care simulation. Clinical Simulation in Nursing, 14, 21-28. https://doi.org/10.1016/j.ecns.2017.10.006

Anderson, N. E., Kent, B., \& Owens, R. G. (2015). Experiencing patient death in clinical practice: Nurses' recollections of their earliest memorable patient death. International Journal of Nursing Studies, 52(3), 695-704. https://doi.org/10.1016/j.ijnurstu.2014.12.005

Bakan, A. B., \& Arli, S. K. (2018). Comparison of attitudes toward death between university students who receive nursing education and who receive religious education. Journal of Religion and Health, 57(6), 2389-2397. https://doi.org/10.1007/s10943-018-0609-z

Barrere, C., \& Durkin, A. (2014). Finding the right words: The experience of new nurses after ELNEC education integration into a BSN curriculum. Medsurg Nursing, 23(1), 35-43.

Baykara, G. Z., Keles, S., Demir Karabulut, S., Gul, S., Eren, H., Durmus Iskender, M., Yildiz, A., Kavas, M. V., \& Yalim, N. Y. (2020). The effect of professional education on medical and nursing students' attitudes toward death. Death Studies. https://doi.org/10.1080/07481187.2020.1850546

Brooks, L. A., Manias, E., \& Nicholson, P. (2017). Communication and decision-making about end-oflife care in the intensive care unit. American Journal of Critical Care, 26(4), 336-341. https://doi. org/10.4037/ajcc2017774

Bryan, L. (2007). Should ward nurses hide death from other patients? End of Life Care, 1(1), 79-86. https://doi.org/10.1136/EOLC-01-01.12

Carey, L. B. (2021). COVID-19, nursing, pediatrics and measuring religion and health. Journal of Religion and Health, 60(1), 1-4. https://doi.org/10.1007/s10943-020-01174-6

Cerit, B. (2019). Influence of training on first-year nursing department students' attitudes on death and caring for dying patients: A single-group pretest-posttest experimental study. OMEGA Journal of Death and Dying, 78(4), 335-347. https://doi.org/10.1177/0030222817748838

Cerit, B., Çoşkun, S., Çalışkan, M. A., \& Temelli, G. (2021). The relationship between nurses' ethical sensitivity levels and their attitudes toward principles about die with dignity. Journal of Religion and Health, 60(1), 162-177. https://doi.org/10.1007/s10943-020-01102-8 
Conner, N. E., Loerzel, V. W., \& Uddin, N. (2014). Nursing student end-of-life care attitudes after an online death and dying course. Journal of Hospice \& Palliative Nursing, 16(6), 374-382. https:// doi.org/10.1097/njh.0000000000000080

Dalal, S., \& Bruera, E. (2017). End-of-life care matters: Palliative cancer care results in better care and lower costs. The Oncologist, 22(4), 361-368. https://doi.org/10.1634/theoncologist.2016-0277

Dalcalı, K. B., Can, Ş, \& Durgun, H. (2020). Emotional responses of neonatal intensive care nurses to neonatal death. OMEGA Journal of Death and Dying. https://doi.org/10.1177/0030222820971880

De Witt Jansen, B., Brazil, K., Passmore, P., Buchanan, H., Maxwell, D., McIlfactrick, S. J., Morgan, S. M., Watson, M., \& Parsons, C. (2017). Nurses' experiences of pain management for people with advanced dementia approaching the end of life: A qualitative study. Journal of Clinical Nursing, 26(9-10), 1234-1244. https://doi.org/10.1111/jocn.13442

Dobrowolska, B., Mazur, E., Pilewska-Kozak, A., Dońka, K., Kosicka, B., \& Palese, A. (2019). Predicted difficulties, educational needs, and interest in working in end of life care among nursing and medical students. Nurse Education Today, 83, 104194. https://doi.org/10.1016/j.nedt.2019.08.012

Dong, F., Zheng, R., Chen, X., Wang, Y., Zhou, H., \& Sun, R. (2016). Caring for dying cancer patients in the Chinese cultural context: A qualitative study from the perspectives of physicians and nurses. European Journal of Oncology Nursing, 21, 189-196. https://doi.org/10.1016/j.ejon.2015.10.003

Erdoğan, S., Nahçıvan, N., \& Esin, M. N. (2014). Hemşirelikte Araştırma: Süreç, Uygulama ve Kritik. Nobel Tip Kitapevleri.

Ferguson, R., \& Cosby, P. (2017). Nursing students' attitudes and experiences toward end-of-life care: A mixed methods study using simulation. Clinical Simulation in Nursing, 13(8), 343-346. https://doi. org/10.1016/j.ecns.2017.03.006

Gibbins, J., McCoubrie, R., \& Forbes, K. (2011). Why are newly qualified doctors unprepared to care for patients at the end of life? Medical Education, 45(4), 389-399. https://doi.org/10.1111/j.1365-2923. 2010.03873.x

Gillan, P. C., Parmenter, G., van der Riet, P. J., \& Jeong, S. (2013). The experience of end of life care simulation at a rural Australian University. Nurse Education Today, 33(11), 1435-1439. https://doi. org/10.1016/j.nedt.2012.11.015

Gillan, P. C., van der Riet, P., \& Jeong, S. (2016). Australian nursing students' stories of end-of-life care simulation. Nursing \& Health Sciences, 18(1), 64-69. https://doi.org/10.1111/nhs.12233

Glover, T. L., Garvan, C., Nealis, R. M., Citty, S. W., \& Derrico, D. J. (2017). Improving end-of-life care knowledge among senior baccalaureate nursing students. American Journal of Hospice and Palliative Medicine ${ }^{\circledR}, 34(10)$, 938-945. https://doi.org/10.1177/1049909117693214

Gómez-Vírseda, C., de Maeseneer, Y., \& Gastmans, C. (2020). Relational autonomy in end-of-life care ethics: A contextualized approach to real-life complexities. BMC Medical Ethics, 21(1), 50. https:// doi.org/10.1186/s12910-020-00495-1

Graneheim, U. H., \& Lundman, B. (2004). Qualitative content analysis in nursing research: Concepts, procedures and measures to achieve trustworthiness. Nurse Education Today, 24(2), 105-112. https://doi.org/10.1016/j.nedt.2003.10.001

Henoch, I., Melin-Johansson, C., Bergh, I., Strang, S., Ek, K., Hammarlund, K., Lundh Hagelin, C., Westin, L., Österlind, J., \& Browall, M. (2017). Undergraduate nursing students' attitudes and preparedness toward caring for dying persons-A longitudinal study. Nurse Education in Practice, 26, 12-20. https://doi.org/10.1016/j.nepr.2017.06.007

Hsu, J.C.-W., Hall, K. H., \& Jaye, C. (2021). Patient-physician spiritual interactions and ethics in end-oflife care. Journal for the Study of Spirituality, 11(1), 24-33. https://doi.org/10.1080/20440243.2020. 1858519

Huang, C. C., Chen, J. Y., \& Chiang, H. H. (2016). The transformation process in nurses caring for dying patients. The Journal of Nursing Research, 24(2), 109-117. https://doi.org/10.1097/jnr.0000000000 000160

Izumi, S., Nagae, H., Sakurai, C., \& Imamura, E. (2012). Defining end-of-life care from perspectives of nursing ethics. Nursing Ethics, 19(5), 608-618. https://doi.org/10.1177/0969733011436205

Jang, S. K., Park, W. H., Kim, H.-I., \& Chang, S. O. (2019). Exploring nurses' end-of-life care for dying patients in the ICU using focus group interviews. Intensive and Critical Care Nursing, 52, 3-8. https://doi.org/10.1016/j.iccn.2018.09.007

Jeffers, S. (2014). Nurse faculty perceptions of end-of-life education in the clinical setting: A phenomenological perspective. Nurse Education in Practice, 14(5), 455-460. https://doi.org/10.1016/j.nepr. 2014.03.009 
Kisorio, L. C., \& Langley, G. C. (2016). Intensive care nurses' experiences of end-of-life care. Intensive and Critical Care Nursing, 33, 30-38. https://doi.org/10.1016/j.iccn.2015.11.002

Kudubes, A. A., Ak1l, Z. K., Bektas, M., \& Bektas, İ. (2021). Nurses' attitudes towards death and their effects on spirituality and spiritual care. Journal of Religion and Health, 60(1), 153-161. https://doi. org/10.1007/s10943-019-00927-2

Kümbetoğlu, B. (2017). Sosyolojide ve Antropolojide Niteliksel Yöntem ve araştırma (5th edn.). Bağlam Yayıncilık.

Laporte, P., Juvet, T., Desbiens, J.-F., Tapp, D., Pasquier, J., \& Bornet, M.-A. (2020). Factors affecting attitudes towards caring for terminally ill patients among nursing students in Switzerland: A cross-sectional study. British Medical Journal Open, 10(9), e037553. https://doi.org/10.1136/bmjop en-2020-037553

Leget, C., \& Kohlen, H. (2020). End of life: Care ethical perspectives. In N. Emmerich, P. Mallia, B. Gordijn, \& F. Pistoia (Eds.), Contemporary European perspectives on the ethics of end of life care (pp. 75-92). Cham: Springer. https://doi.org/10.1007/978-3-030-40033-0_5

Li, J., Smothers, A., Fang, W., \& Borland, M. (2019). Undergraduate nursing students' perception of endof-life care education placement in the nursing curriculum. Journal of Hospice and Palliative Nursing, 21(5), E12-E18. https://doi.org/10.1097/njh.0000000000000533

Liu, Y.-C., \& Chiang, H.-H. (2017). From vulnerability to passion in the end-of-life care: The lived experience of nurses. European Journal of Oncology Nursing, 31, 30-36. https://doi.org/10.1016/j.ejon. 2017.09.002

Mak, Y. W., Chiang, V. C. L., \& Chui, W. T. (2013). Experiences and perceptions of nurses caring for dying patients and families in the acute medical admission setting. International Journal of Palliative Nursing, 19(9), 423-431. https://doi.org/10.12968/ijpn.2013.19.9.423

Noome, M., Dijkstra, B. M., van Leeuwen, E., \& Vloet, L. C. M. (2016). Exploring family experiences of nursing aspects of end-of-life care in the ICU: A qualitative study. Intensive and Critical Care Nursing, 33, 56-64. https://doi.org/10.1016/j.iccn.2015.12.004

Özarslan, A. D. (2017). Medicalization of death and intensive care unit as a heterotopia. MSGSÜ Sosyal Bilimler Dergisi, 1(15), 30-44.

Özgönül, M. L., Kırca, N., \& Bademli, K. (2020). Hemşirelik Öğrencilerinin Etik Sorunlara Yaklaşım Durumlarının Belirlenmesi. Tıp Eğitimi Dünyası, 19(59), 18-28. https://doi.org/10.25282/ted. 691189

Parry, M. (2011). Student nurses' experience of their first death in clinical practice. International Journal of Palliative Nursing, 17(9), 448-453. https://doi.org/10.12968/ijpn.2011.17.9.448

Şahin, M., Demirkıran, F., \& Adana, F. (2016). Hemşirelik Öğrencilerinde Ölüm Kaygısı, Ölmekte Olan Bireye Bakım Verme İsteği ve Etkileyen Faktörler. Journal of Psychiatric Nursing/psikiyatri Hemsireleri Dernegi. https://doi.org/10.5505/phd.2016.66588

Shaw, P. A., \& Abbott, M. A. (2017). High-fidelity simulation: Teaching end-of-life care. Nurse Education Today, 49, 8-11. https://doi.org/10.1016/j.nedt.2016.10.014

Svenaeus, F. (2020). To die well: The phenomenology of suffering and end of life ethics. Medicine, Health Care and Philosophy, 23(3), 335-342. https://doi.org/10.1007/s11019-019-09914-6

Tamaki, T., Inumaru, A., Yokoi, Y., Fujii, M., Tomita, M., Inoue, Y., Kido, M., Ohno, Y., \& Tsujikawa, M. (2019). The effectiveness of end-of-life care simulation in undergraduate nursing education: A randomized controlled trial. Nurse Education Today, 76, 1-7. https://doi.org/10.1016/j.nedt.2019. 01.005

Temelli, G., \& Cerit, B. (2019). Perceptions of palliative care nurses related to death and palliative care practices. OMEGA Journal of Death and Dying. https://doi.org/10.1177/0030222819890457

Tüzer, H., Kırca, K., \& Özveren, H. (2020). Investigation of nursing students' attitudes towards death and their perceptions of spirituality and spiritual care. Journal of Religion and Health, 59(4), 21772190. https://doi.org/10.1007/s10943-020-01004-9

Uysal, N., Ceylan, E., \& Koç, A. (2019). Hemşirelik bölümü öğrencilerinin ölmekte olan bireyin bakımına ilişkin tutumları. Gümüşhane Üniversitesi Să̆llk Bilimleri Dergisi, 8(1), 98-105.

Üzen Cura, Ş. (2021). Nursing students' spiritual orientations and their attitudes toward the principles of dying with dignity: A sample from Turkey. Journal of Religion and Health, 60(1), 221-231. https:// doi.org/10.1007/s10943-020-01029-0

Wang, L., Li, C., Zhang, Q., \& Li, Y. (2018). Clinical nurses' attitudes towards death and caring for dying patients in China. International Journal of Palliative Nursing, 24(1), 33-39. https://doi.org/ 10.12968/ijpn.2018.24.1.33 
Wong, E.L.-Y., Kiang, N., Chung, R.Y.-N., Lau, J., Chau, P.Y.-K., Wong, S.Y.-S., Woo, J., Chan, E.Y.Y., \& Yeoh, E.-K. (2020). Quality of palliative and end-of-life care in Hong Kong: Perspectives of healthcare providers. International Journal of Environmental Research and Public Health, 17(14), 5130 .

Yang, H., Lu, Y., Hou, X., Guo, R., Wang, Y., Liu, L., Gu, Y., \& Sun, H. (2019). Nurse-rated good death of Chinese terminally ill patients with cancer: A cross-sectional study. European Journal of Cancer Care, 28(6), e13147. https://doi.org/10.1111/ecc.13147

Yiğitoğlu, T. G., \& Özer, G. F. (2012). Determining death anxiety among health school students. Journal of Human Sciences, 9(2), 303-317.

Zheng, R.-S., Guo, Q.-H., Dong, F.-Q., \& Owens, R. G. (2015). Chinese oncology nurses' experience on caring for dying patients who are on their final days: A qualitative study. International Journal of Nursing Studies, 52(1), 288-296. https://doi.org/10.1016/j.ijnurstu.2014.09.009

Zheng, R., Lee, S. F., \& Bloomer, M. J. (2016). How new graduate nurses experience patient death: A systematic review and qualitative meta-synthesis. International Journal of Nursing Studies, 53, 320-330. https://doi.org/10.1016/j.ijnurstu.2015.09.013

Publisher's Note Springer Nature remains neutral with regard to jurisdictional claims in published maps and institutional affiliations. 